R O C Z N I I N A U K P R A W Y C H

Tom XXXI, numer 3 - 2021, s. 115-126

DOI: http://doi.org/10.18290/rnp21313.7

MARTA SAGAN-MARTKO

Uniwersytet Rzeszowski

msagan@ur.edu.pl

ORCID: https://orcid.org/0000-0003-1385-2141

\title{
UPOWAŻNIENIE DO UJAWNIENIA TAJEMNICY BANKOWEJ OSOBIE TRZECIEJ A PEŁNOMOCNICTWO*
}

\author{
AUTHORIZATION TO DISCLOSE BANKING SECRECY TO A THIRD PARTY \\ AND A POWER OF ATTORNEY
}

\begin{abstract}
The article deals with the issue of third party access to confidential information covered by banking secrecy. Under the current provisions of banking law, it should be authorized by the beneficiary of secrecy, however, both in the doctrine and practice of applying the law, there are inconsistent positions regarding the possibility of providing such information by a bank to a person holding a power of attorney. In this context, the research problem is an attempt to answer the question what differences in the form and nature of the authorization and power of attorney may affect the decision regarding disclosure of information covered by banking secrecy.
\end{abstract}

Keywords: power of attorney, banking secrecy, access

\section{WPROWADZENIE}

Przedmiotem artykułu jest próba rozstrzygnięcia kwestii budzącej wątpliwości zarówno w doktrynie, jak i praktyce stosowania prawa, a mianowicie, jakim dokumentem może legitymować się osoba trzecia w celu uzyskania informacji dotyczących osoby fizycznej, które objęte są tajemnicą bankową, oraz jaka powinna być jego forma. Pomimo tego, że zagadnienie to jest ure-

* Artykuł został przygotowany na podstawie podrozdziału Pelnomocnictwo $w$ kontekście tajemnicy bankowej, [w:] M. SAGAN, Tajemnica bankowa a prawo do prywatności w prawie polskim, Rzeszów: Wydawnictwo Uniwersytetu Rzeszowskiego 2021, s. 75-78, który został zmodyfikowany, znacząco poszerzony i uaktualniony. 
gulowane w Prawie bankowym ${ }^{1}$, to wykładnia obowiązujących przepisów oraz praktyka stosowania nie są jednolite. Często spotykanym zjawiskiem jest odmowa załatwienia przez bank sprawy czy też dokonania określonej czynności, w sytuacji kiedy strona zastępowana jest przez profesjonalnego pełnomocnika legitymującego się pełnomocnictwem udzielonym $\mathrm{w}$ formie pisemnej $^{2}$. Banki, mimo braku podstaw do tego rodzaju działań, często wymagają pełnomocnictwa $\mathrm{w}$ formie aktu notarialnego ${ }^{3}$. W artykule przedstawiono $\mathrm{w}$ zarysie rolę instytucji tajemnicy bankowej $\mathrm{z}$ uwzględnieniem jej gwarancyjnego charakteru, podjęto zagadnienie charakteru prawnego pełnomocnictwa i upoważnienia oraz przedstawiono wnioski. Badania przeprowadzono przy użyciu metody formalnodogmatycznej.

\section{STATUS INFORMACJI OBJĘTYCH TAJEMNICĄ BANKOWA}

Podmiot $^{4}$, którego dotyczą informacje objęte tajemnicą bankową, jest ich wyłącznym dysponentem, co oznacza, że może dane te swobodnie rozpowszechniać. Natomiast bank, do momentu wyrażenia zgody na ujawnienie danych objętych tajemnicą bankową, ma obowiązek zachowania ich w dys-

\footnotetext{
${ }^{1}$ Ustawa z dnia 29 sierpnia 1997 r. - Prawo bankowe, tekst jedn.: Dz.U. z 2020 r., poz. 1896 ze zm. [dalej: pr.b.].

${ }^{2} \mathrm{~W}$ zależności od rodzaju sprawy, do załatwienia której został umocowany pełnomocnik, należy mieć na względzie przepisy materialne - art. 98 i n. ustawy z dnia 23 kwietnia 1964 r. - Kodeks cywilny, tekst jedn.: Dz.U. z 2020 r., poz. 1740 ze zm. [dalej: k.c.], lub procesowe - art. 88 i n. ustawy z dnia 17 listopada 1964 r. - Kodeks postępowania cywilnego, tekst jedn.: Dz.U. z 2020 r., poz. 1575 ze zm. [dalej: k.p.c.].

$\mathrm{Na}$ temat możliwości uzyskania informacji objętych tajemnicą bankową przez pełnomocników (też procesowych) zob. M. BĄCZYK, Zagadnienie dostępu petnomocnika do informacji objętych tajemnica bankowa, „Prawo Bankowe” 1999, nr 2(24), s. 85-89.

${ }^{3} \mathrm{Na}$ powyższy problem zwróciły uwagę władze Naczelnej Rady Adwokackiej. Zob. http:// www.adwokatura.pl/z-zycia-nra/knf-po-pismie-nra-interweniuje-ws-niehonorowania-przez-banki -pelnomocnictw/ i zamieszczone tam stanowiska Naczelnej Rady Adwokackiej oraz Komisji Nadzoru Finansowego [dostęp: 24.03.2020].

${ }^{4} \mathrm{~W}$ artykule ograniczono się do przedstawienia problematyki dotyczącej osób fizycznych. Samo zagadnienie prawa do prywatności osób prawnych nie jest traktowane $\mathrm{w}$ doktrynie jednolicie. Zgodnie z jednym ze stanowisk sporne pozostaje już samo przyznanie im prawa do prywatności ze względu na jego charakter. Por. A. SzPUNAR, Ochrona dóbr osobistych, Warszawa: PWN 1979, s. 33. Autor podnosi, iż prawo to z uwagi na swój charakter może zostać przyznane wyłącznie osobom fizycznym. Pogląd przeciwny głosi, że mimo istnienia odmiennej natury osób prawnych, nie można całkowicie eliminować możliwości istnienia analogicznego dobra osobistego w przypadku osób prawnych. Por. P. KsIĘŻAK, Komentarz do art. 43 Kodeksu cywilnego, [w:] Kodeks cywilny. Komentarz. Część ogólna, red. P. Księżak, M. Pyziak-Szafnicka, LEX nr 8935, stanowczo stwierdzający, iż dobra osobiste przysługują wszystkim osobom prawnym.
} 
$\mathrm{krecji}^{5}$. Sfera życia prywatnego określana jest inaczej, jako prawo do prywatności, bowiem stanowi zespół okoliczności i informacji z życia osobistego i rodzinnego, ujawnianych tylko wąskiemu gronu najbliższych osób. W treści art. 104 ust. 1 pr.b. wyrażona została zasada maksymalizmu ${ }^{6}$ zakresu informacji stanowiących tajemnicę bankową, które to ujęcie znajduje swoje uzasadnienie $\mathrm{w}$ celu tej instytucji. Jest nim ochrona prawna życia prywatnego posiadacza rachunku ${ }^{7}$. Tajemnica bankowa ${ }^{8}$ to instytucja o charakterze gwarancyjnym. Ujawnienie informacji objętych tajemnicą bankową umożliwia poznanie między innymi posiadanych przez daną osobę środków finansowych. Status materialny w odniesieniu do osób fizycznych współcześnie decyduje o jej pozycji w hierarchii społecznej ${ }^{9}$. Status społeczno-ekonomiczny zawiera trzy wymiary, tj. wymiar edukacyjny, zawodowy i ekonomiczny. Uznawane są one za podstawę systemu stratyfikacyjnego nowoczesnych społeczeństw ${ }^{10}$, natomiast nierówności w sferze ekonomicznej nie pozostają bez znaczenia dla utrwalania się już istniejących podziałów społecznych ${ }^{11}$. Bez wątpienia informacje objęte tajemnicą bankową pozwalają na odtworzenie statusu materialnego jednostki, który stanowi element jej sfery intymnej,

${ }^{5}$ K. Królikowska, Komentarz do art. 104, [w:] B. BAJor, L. Kociucki, J.M. KondeK, K. KRólikowsKa, Prawo bankowe. Komentarz do przepisów cywilnoprawnych, Wolters Kluwer, Warszawa 2020, https://sip.lex.pl/\#/commentary/587830967/628407/bajor-barbara-i-in-prawobankowe-komentarz-do-przepisow-cywilnoprawnych [dostęp: 6.03.2021].

${ }^{6}$ Tak np. J. BYRSKI, Tajemnica bankowa - aktualne regulacje oraz nowe wyzwania, [w:] Ochrona klienta na rynku ustug finansowych $w$ świetle aktualnych problemów i regulacji prawnych, red. E. Rutkowska-Tomaszewska, Warszawa: C.H. Beck 2017, s. 237-252; G. SiKOrSKI, Prawo bankowe. Komentarz, Warszawa: C.H. Beck 2015, s. 285.

${ }^{7}$ Wyrok Sądu Apelacyjnego w Łodzi z 13 czerwca 2018 r., I ACa 1320/17, LEX nr 2571386.

${ }^{8}$ Istota tej instytucji została uregulowana w art. 104 pr.b.

${ }^{9}$ Struktura społeczna stanowi uporządkowaną całość, regulującą stosunki między jej elementami składowymi. Układ ten występuje zarówno na poziomie globalnym, jak i w mikroskali (tzw. makrostruktura i mikrostruktura). Należy podkreślić, że jego istota tkwi w sieci relacji pomiędzy jednostkami, a nie w samych jednostkach czy rolach społecznych, jakie pełnią. P. SzTOMPKA, Socjologia. Analiza społeczeństwa, Kraków: Znak 2012, s. 166.

${ }^{10}$ E. Rokicka, M. Petelewicz, Subiektywna jakość życia a status społeczno-ekonomiczny. Na przykładzie mieszkańców Łodzi, „Przegląd Socjologiczny” 63 (2014), nr 2, s. 143-161. Autorki wskazują, że w badaniach spotykano się z dużą liczbą odmów odpowiedzi na pytania o zarobki i dochody ze względu na przypisany im status wiedzy wrażliwej. Coraz częściej wywołują negatywne reakcje respondentów oraz niechęć udzielania na nie odpowiedzi.

${ }^{11}$ A. KARWIŃSKA, Uwarunkowania dobrego funkcjonowania społeczeństwa. Znaczenie gospodarki społecznej, „Ekonomia Społeczna” 2010, nr 1, s. 7-25. Zob. K. JANICKA, K.M. SŁOMCZYŃSKI, Struktura spoteczna w Polsce: klasowy wymiar nierówności, „Przegląd Socjologiczny” 63 (2014), nr 2, s. 55-72. Wyniki badań przedstawione w artykule wskazują na zjawisko polaryzacji w społeczeństwie związane m.in. z osiąganymi dochodami. 
a znając go można z łatwością stwierdzić, jaki styl życia prowadzi dana osoba, skąd czerpie dochody, na co je przeznacza, a także gdzie i kiedy bywa.

Wobec powyższego informacje objęte tajemnicą bankową dotyczącą osób fizycznych, niewątpliwie są elementem prawa do prywatności. Określa się go w literaturze przedmiotu prawem do prywatności finansowej. Oznacza to, że jako część składająca się na prawo do prywatności winny korzystać ze wzmocnionej ochrony prawnej. Trzeba mieć jednak na uwadze, że skoro beneficjent tajemnicy bankowej jest uprawniony do decydowania komu i jakie informacje konfidencjonalne bank powinien udostępnić, to niewskazane są nadmierne utrudnienia $w$ ich udzielaniu spowodowane różnymi stanowiskami dotyczącymi samego dokumentu upoważniającego do uzyskania takich informacji.

\section{POJĘCIE I CHARAKTER PEŁNOMOCNICTWA W ZARYSIE}

Termin „pełnomocnictwo” jest wieloznaczny ${ }^{12}$. W doktrynie używa się go na określenie mocy prawnej przysługującej pełnomocnikowi ${ }^{13}$; w znaczeniu czynności prawnej udzielenia takiej mocy - określane jest jako czynność prawna mocodawcy, w skład której wchodzi oświadczenie woli tej treści, iż pełnomocnikowi nadaje się moc oświadczenia woli w imieniu i ze skutkiem dla reprezentowanego ${ }^{14}$ bądź też jako sam dokument pełnomocnictwa ${ }^{15}$. W kodeksie postępowania cywilnego przez pełnomocnictwo rozumie się sam dokument „materializujący” umocowanie ${ }^{16}$, niemający charakteru konstytutyw-

\footnotetext{
${ }^{12}$ Przeglądu definicji pełnomocnictwa cywilnego materialnego i procesowego dokonał P. WIDERSKI, Pelnomocnictwo w prawie polskim, Warszawa: Wolters Kluwer 2018, s. 71-88.

${ }^{13}$ Zgodnie z teorią reprezentacji, której twórcą był R. Ihering, przy przedstawicielstwie podmiotem działającym jest przedstawiciel. Stanowi ona opozycję wobec teorii fikcji Savigny'ego, uznającej reprezentowanego za właściwy podmiot czynności dokonanej przez przedstawiciela. Por. A. Wolter, J. Ignatowicz, K. Stefaniuk, Prawo cywilne. Zarys części ogólnej, Warszawa: Wolters Kluwer 2001, s. 341.

${ }^{14}$ Tak np. F. Zoll, Prawo cywilne, t. I: Część ogólna, Poznań: Wojewódzki Instytut Wydawniczy 1931, s. 230; A. SzPUNAR, Udzielenie petnomocnictwa, „Przegląd Sądowy” 1993, nr 9, s. 1834. Zgodnie z poglądem odmiennym przez pełnomocnictwo rozumie się moc prawną reprezentowania udzieloną pełnomocnikowi w drodze czynności prawnej mocodawcy. Por. W. GórSKI, E. KitŁowski, Prawo cywilne, Warszawa: PWN 1974, s. 70. Za: M. SMYK, Pelnomocnictwo wedtug kodeksu cywilnego, Warszawa: Wolters Kluwer 2010, s. 59-61.

${ }^{15}$ A. SzPUNAR, Stanowisko prawne petnomocnika, „Przegląd Notarialny” 1948, nr 1/2, s. 51-76.

${ }^{16}$ Art. $89 \S 1,90,126 \S 3$ k.p.c.
} 
nego, a będący dowodem potwierdzającym istnienie umocowania pełnomocnika do działania $\mathrm{w}$ imieniu strony ${ }^{17}$.

Udzielenie pełnomocnictwa innej osobie do działania w imieniu mocodawcy, w oznaczonym w pełnomocnictwie zakresie, następuje w drodze jednostronnej czynności prawnej. Powoduje ono powstanie stosunku pełnomocnictwa, którego stronami są mocodawca i pełnomocnik ${ }^{18}$. Jako przyczynę niejednolitego rozumienia terminu „pełnomocnictwo” na gruncie kodeksu cywilnego wskazuje się niejednoznaczność unormowania m.in. art. 96 k.c. ${ }^{19}$

W zależności od rodzaju sprawy przedmiotem rozważań dotyczących pełnomocnictwa dla osoby upoważnionej do uzyskania informacji objętych tajemnicą bankową ${ }^{20}$ może być zarówno pełnomocnictwo materialne, jak i procesowe $^{21}$.

\section{CHARAKTER I FORMA UPOWAŻNIENIA DO UJAWNIENIA TAJEMNICY BANKOWEJ}

Artykuł 104 ust. 3 zd. drugie pr.b. stanowi, że osobom trzecim informacje podlegające ochronie jako tajemnica bankowa mogą być ujawnione, z zastrzeżeniem art. 105, art. 106a i art. 106b pr.b., wyłącznie gdy osoba, której informacje te dotyczą, na piśmie upoważni bank do przekazania określonych informacji wskazanej przez siebie osobie lub jednostce organizacyjnej. Upoważnienie może być także wyrażone w postaci elektronicznej. W takim

${ }^{17}$ Por. J. SoBkowski, Petnomocnictwo procesowe, jego istota, powstanie i wygaśnięcie, Poznań: UAM 1967, s. 97.

${ }^{18}$ Wyrok Sądu Najwyższego z dnia 28 lutego 2018 r. II CSK 228/17, LEX nr 2486810.

${ }^{19}$ M. SMYK, Petnomocnictwo, s. 57. Na niekonsekwencję ustawodawcy wskazują także art. 102 k.c., w którym terminu ,pełnomocnictwo” użyto w znaczeniu dokumentu, art. 99 k.c. - w rozumieniu czynności prawnej stanowiącej źródło pełnomocnictwa, czy też art. 101 k.c., gdzie przez „pełnomocnictwo" rozumie się umocowanie pełnomocnika. Zob. M. BALWICKA-SzCZYRBA, Przepisy ogólne o pelnomocnictwie w kodeksie cywilnym, [w:] M. BALwICKA-SzCZYRBA, M. GLICZ, A. SylwestrZak, Petnomocnictwo. Komentarz, Warszawa: Wolters Kluwer 2020, s. 47-150.

${ }^{20}$ Zob. M. BĄCZYK, Petnomocnictwo zwiazane ze stosunkiem rachunku bankowego w praktyce bankowej, „Studia Iuridica Toruniensia” 2020, t. 26, s. 21-48.

${ }^{21}$ Zob. przypis 14. Komisja Nadzoru Finansowego wskazuje na materialny charakter upoważnienia do ujawnienia informacji objętych tajemnicą bankową. Natomiast jeżeli chodzi o pełnomocnictwo, to można wyobrazić sobie sytuację, w której udzielono pełnomocnictwa o charakterze materialnym, czyli wyłącznie do uzyskania wskazanych informacji objętych tajemnicą bankową, bądź też procesowym - jeżeli czynność procesowa obejmie swoim zakresem uzyskanie i wykorzystanie danych konfidencjonalnych (np. dołączenie do pozwu wykazu operacji dokonywanych $\mathrm{z}$ rachunku bankowego mocodawcy). 
przypadku bank obowiązany jest do utrwalenia wyrażonego w ten sposób upoważnienia na informatycznym nośniku danych w rozumieniu art. 3 pkt 1 ustawy z dnia 17 lutego 2005 r. o informatyzacji działalności podmiotów realizujących zadania publiczne ${ }^{22}$. W praktyce oznacza to, że dokument elektroniczny stanowi plik komputerowy ${ }^{23}$.

Zgodnie ze stanowiskiem Komisji Nadzoru Finansowego

upoważnienie takie nie jest tożsame z pełnomocnictwem. Bank nie może udzielić informacji objętych tajemnicą bankową w przypadku, gdy jest to ogólne pełnomocnictwo lub pełnomocnictwo procesowe, które upoważnia do określonych czynności, lecz nie zawiera upoważnienia do przekazania określonych informacji wskazanej przez siebie osobie. Tylko upoważnienie określające, że klient upoważnia bank do przekazania określonych informacji (należy wskazać jakich) wskazanej przez siebie osobie, upoważnia bank do udzielenia takich informacji. Upoważnienie takie bowiem ma charakter materialny, a nie procesowy ${ }^{24}$.

Mając to na uwadze, należy stwierdzić, że przepisy wprowadzające wymaganie udzielenia przedmiotowego upoważnienia na piśmie nie określają, w jakiego rodzaju dokumencie musi być ono dokonane (dopuszcza się jego udzielenie w odrębnym dokumencie, ale także umieszczenie upoważnienia w treści indywidualnych umów bankowych, czyli tzw. klauzul upoważniających w umowach rachunku bankowego czy kredytowych ${ }^{25}$ ). Użycie przez

${ }^{22}$ Ustawa z dnia 17 lutego 2005 r. o informatyzacji działalności podmiotów realizujących zadania publiczne, tekst jedn.: Dz.U. z 2020 r., poz. 346 ze zm. Zgodnie z powołanym przepisem, informatyczny nośnik danych to materiał lub urządzenie służące do zapisywania, przechowywania i odczytywania danych w postaci cyfrowej. Na podstawie art. 3 ust. 1 pkt 2 tejże ustawy dokument elektroniczny to stanowiący odrębną całość znaczeniową zbiór danych uporządkowanych w określonej strukturze wewnętrznej i zapisany na informatycznym nośniku danych. Trzeba mieć na względzie, że co do zasady regulacja ta dotyczy wyłącznie czynności dokonywanych pomiędzy organami administracji publicznej oraz pomiędzy organami a interesantami. Nie ma zastosowania do czynności prawa cywilnego materialnego i procesowego Por. D. SzosteK, M. ŚwIERCZYŃSKI, Moc dowodowa dokumentu elektronicznego w postępowaniu cywilnym, „Monitor Prawniczy" 2007, nr 17, https://czasopisma.beck.pl/index.php?id=186\&tx_journals_articleshow\%5Bartic $1 \mathrm{e} \% 5 \mathrm{D}=29276 \&$ tx_journals_articleshow $\% 5 \mathrm{Baction} \% 5 \mathrm{D}=$ show\&tx_journals_articleshow $\% 5 \mathrm{Bcontroll}$ er\%5D=Article\&no_cache=1 [dostęp: 12.03.2021].

${ }^{23}$ Wydruk komputerowy może być również traktowany jako dokument elektroniczny, pod warunkiem, że zastosowano w nim podpis elektroniczny - tak w wyroku Wojewódzkiego Sądu Administracyjnego w Gliwicach z dnia 18 grudnia 2018 r., III SA/Gl 916/18, LEX nr 2622861.

${ }^{24}$ Pismo KNF z dnia 8 grudnia 2015 r., DRB/DRBI/075/21/4/15, https://www.adwokatura.pl/ admin/wgrane_pliki/file-odpowiedzknf1-15339.pdf [dostęp: 3.03.2021].

${ }^{25} \mathrm{~W}$ przypadku wzorców umownych i regulaminów istnieje konieczność zachowania warunków formalnych upoważnienia określonych w art. 104 ust. 3 pr.b. Por. K. KRÓLIKOWSKA, Komentarz do art. 104. Wprowadzenie do wzorca umownego klauzuli upoważniającej bank do przekazywania informacji osobom trzecim z wyłączeniem konieczności uzyskania zgody klienta banku 
ustawodawcę zwrotu „wskazanej przez siebie osobie lub jednostce organizacyjnej" implikuje - po pierwsze - konieczność wskazania podmiotu, który ma być odbiorcą informacji przekazanych mu przez bank, a po drugie - że podmioty te muszą być określone w sposób zindywidualizowany.

Upoważnienie do udzielenia informacji objętych tajemnicą bankową może być w każdym czasie odwołane. Beneficjent może także zmodyfikować jego zakres podmiotowy i przedmiotowy, a bank nie może odmówić przyjęcia upoważnienia, co per analogiam ma zastosowanie również do jego zmiany lub odwołania ${ }^{26}$. Użyte przez ustawodawcę $\mathrm{w}$ treści przytoczonego przepisu określenie „przez siebie” oznacza, iż upoważnienie to może być udzielone osobiście przez beneficjenta tajemnicy bankowej bądź też przez jego pełnomocnika lub prokurenta ${ }^{27}$.

Podsumowując kwestię formy upoważnienia do ujawnienia przez bank osobie trzeciej informacji stanowiących tajemnicę bankową, dla jego skuteczności wystarczające jest jego udzielenie „na piśmie”. Nie jest to pojęcie tożsame $\mathrm{z}$ pojęciem zwykłej formy pisemnej przewidzianej w art. 78 k.c., bowiem

do zachowania pisemnego charakteru umowy wystarcza, aby tożsamość stron dawała się bez trudu ustalić, a treść umowy była w każdej chwili osiągalna, możliwa do odtworzenia w oryginalnym kształcie i powielana w zwykłym toku czynności, tj. np. za pomocą powszechnie stosowanego oprogramowania. Utożsamianie konwencjonalnego pojęcia „umowa pisemna" z formą pisemną zwykłą uregulowaną w art. 78 (k.c.) jest interpretacją błędną ${ }^{28}$.

będącego konsumentem, stanowić będzie niedozwoloną klauzulę abuzywną. Por. K. KRÓLIKOwSKA, J. KRÓLIKOWSKI, Zgoda klienta banku na przekazywanie informacji konfidencjonalnych firmom zewnętrznym jako narzędzie gwarancji konstytucyjnego prawa do prywatności, „Studia Iuridica” 2008, t. 49, s. 105-124; J. WRONA, M. PIŁKA, K. BUDZICH, Ustugi bankowe w aspekcie ochrony praw konsumenta. Raport z kontroli wzorców umownych uznanych za niedozwolone, Warszawa 2003, s. 29-37, https://www.uokik.gov.pl/download.php?plik=11214 [dostęp: 8.04.2021].

${ }^{26}$ Beneficjent może decydować także o zakresie czasowym takiego upoważnienia. Zob. M. BĄCZYK, Czy w umowie może być umieszczone upoważnienie przewidziane $w$ przepisie art. 104 ust. 2 prawa bankowego, „Prawo Bankowe” 2000, nr 10, s. 89-92.

${ }^{27}$ Tamże. W przypadku pełnomocnika należy pamiętać, iż w zakresie udzielonego pełnomocnictwa winno wówczas zostać wyszczególnione udzielanie upoważnień dla banku do przekazywania informacji objętych tajemnicą bankową. Sytuacja ta jest odmienna od wskazanego w treści artykułu problemu uzyskania informacji objętych tajemnicą bankową przez osobę legitymującą się pełnomocnictwem, bowiem w tym przypadku mamy do czynienia $\mathrm{z}$ dalszym decydowaniem o tym, komu ujawnić informacje konfidencjonalne.

${ }^{28}$ W. Kocot, Glosa do postanowienia SN z 22.02.2007 r., IV CSK 200/06, poz. 110, „Orzecznictwo Sądów Polskich” 2008, nr 10, poz. 110c, s. 747-754. 
Podobny pogląd wyraził Krzysztof Oplustil, stwierdzając, że

wymóg udzielenia pełnomocnictwa „na piśmie” spełni przesłanie go w formie faksu, jeżeli treść tak udzielonego pełnomocnictwa pozwoli jednoznacznie zidentyfikować osobę akcjonariusza i pełnomocnika. Skoro bowiem pełnomocnictwo to może zostać ważnie udzielone w „postaci elektronicznej”, a więc np. w zwykłym e-mailu, a spółka nie może odmówić uznania jego ważności, to tym bardziej zadość wymogowi identyfikowalności mocodawcy i pełnomocnika czynić będzie papierowy dokument faksu czy wydruk zeskanowanego dokumentu ${ }^{29}$.

Natomiast zgodnie z dyspozycją art. $78 \S 1$ zd. 1 k.c., do zachowania pisemnej formy czynności prawnej wystarcza złożenie własnoręcznego podpisu na dokumencie obejmującym treść oświadczenia woli. W tym przypadku przesłanki, których spełnienie jest niezbędne do zachowania przepisanej formy, to: utrwalenie treści oświadczenia woli w dokumencie sporządzonym w języku pisanym, czyli znakami graficznymi na oznaczenie słów uporządkowanych zgodnie ze strukturą danego języka ${ }^{30}$, oraz opatrzenie dokumentu własnoręcznym podpisem przez osobę składającą oświadczenie ${ }^{31}$. Składając podpis na dokumencie obejmującym oświadczenie woli, podpisujący daje wyraz temu, że dokument zawiera ostateczną, a nie jedynie projektowaną treść danego oświadczenia, oraz że jest ono zupełne i pochodzi od osoby podpisanej ${ }^{32}$. Dokument pełnomocnictwa nie musi zawierać czytelnego podpisu mocodawcy. Podpis ten powinien jednak w wystarczający sposób identyfikować osobę wystawcy ${ }^{33}$. Należy zaznaczyć, że na gruncie k.c. oświadczenie woli złożone $\mathrm{w}$ formie elektronicznej ${ }^{34}$ jest równoważne $\mathrm{z}$ oświadczeniem woli złożonym w formie pisemnej (art. $78^{1} \S 2$ k.c.).

${ }^{29}$ K. Oplustil, Pelnomocnictwo do występowania na walnym zgromadzeniu akcjonariuszy spótki publicznej po nowelizacji k.s.h. ustawa z 5.12.2008 r., „Przegląd Prawa Handlowego” 2009, nr 11, s. 4-12. Pojęcia „postać elektroniczna” i „forma elektroniczna” nie są tożsame. Przez postać elektroniczną należy rozumieć „nośnik” oświadczenia, natomiast forma odnosi się do obowiązku podpisania oświadczenia.

${ }^{30}$ Z. RADWAŃSKI, Elektroniczna forma czynności prawnej, „Monitor Prawniczy” 2001, nr 22, https://czasopisma.beck.pl/monitor-prawniczy/artykul/elektroniczna-forma-czynnosci-prawnej/ [dostęp: 12.03.2021].

${ }^{31}$ P. NAZARUK, Komentarz do art. 78, [w:] Kodeks cywilny. Komentarz, red. J. Ciszewski, P. Nazaruk, https://sip.lex.pl/\#/commentary/587804320/601760 [dostęp: 25.03.2020].

${ }^{32}$ Uchwała Sądu Najwyższego z 30 grudnia 1993 r., III CZP 146/93, Orzecznictwo Sądu Najwyższego. Izba Cywilna 1994, nr 5, poz. 94.

${ }^{33}$ Postanowienie Sądu Najwyższego z 17 sierpnia 2000 r., II CKN 894/00, „Biuletyn Sądu Najwyższego" 2000, nr 10, s. 14.

${ }^{34} \mathrm{Na}$ podstawie art. $78^{1} \S 1$ k.c. do zachowania elektronicznej formy czynności prawnej wystarcza złożenie oświadczenia woli w postaci elektronicznej i opatrzenie go kwalifikowanym podpisem elektronicznym. 
Kolejną kwestią budzącą wątpliwości jest treść upoważnienia, a ściślej rzecz ujmując: czy wzmianka o nim winna znaleźć się w pełnomocnictwie do załatwienia danej sprawy udzielonemu profesjonaliście. Mirosław Bączyk wskazuje, że nie jest konieczne udzielenie upoważnienia do udzielenia tajemnicy bankowej osobie trzeciej odrębnie od pełnomocnictwa, a samo

udzielenie pełnomocnictwa przez stronę umowy bankowej (beneficjenta) tworzy dla pełnomocnika wystarczający tytuł (uprawnienie) do uzyskania informacji objętych tajemnicą bankową, jeżeli takie umocowanie pozostaje skuteczne wobec banku (w świetle postanowień regulaminowych). Mocodawca (beneficjent) nie musi zatem dodatkowo jeszcze upoważniać banku na piśmie do udzielenia informacji pełnomocnikowi jako osobie trzeciej ${ }^{35}$.

Zakres informacji, które mogą zostać przekazane pełnomocnikowi, zależeć miałby wówczas od zasięgu jego umocowania, z uwzględnieniem okoliczności konkretnej sprawy. Zdaniem autorki należy przychylić się do koncepcji E. Fojcik-Mastalskiej.

\section{WNIOSKI}

Mając na uwadze wyżej poczynione rozważania, zasadne wydaje się przyjęcie, że jeżeli dana osoba decyduje się na działanie przez pełnomocnika w celu dokonania określonych czynności, czy też załatwienia sprawy, której drugą stroną jest bank, to ma świadomość o niezbędności jego dostępu do danych objętych tajemnicą bankową. Dodatkowo, profesjonalni pełnomocnicy, czyli adwokaci i radcy prawni zobligowani są do zachowania tajemnicy zawodowej. Jest to argument przemawiający za przychyleniem się do koncepcji uznania pełnomocnictwa jako dokumentu pozwalającego na udzielenie osobie trzeciej informacji objętych tajemnicą bankową.

Pełnomocnictwo ma szerszy zakres niż upoważnienie, o którym mowa w art. 104 ust. 3 pr.b., a przy jego udzielaniu zwykle zachowywana jest bardziej rygorystyczna forma.

Mając na uwadze powszechną praktykę odmowy udzielenia informacji objętych tajemnicą bankową w przypadku pełnomocnictwa, z którego korzystają banki, w celu uniknięcia ewentualnego przedłużenia trybu załatwienia sprawy, można rozważyć umieszczenie w pełnomocnictwie dodatkowej klauzuli. Przykładowa jej treść to: „Na podstawie art. 104 ust. 3 pr.b. upoważniam

${ }^{35}$ M. BĄCZYK, Komentarz do art. 104, [w:] Prawo bankowe. Komentarz, red. E. Fojcik-Mastalska, LEX nr 9095. 
bank do ujawnienia i przekazania wszystkich informacji objętych tajemnicą bankową mojemu pełnomocnikowi, w zakresie mającym związek z prowadzoną sprawą" (opisaną w „głównej” części dokumentu pełnomocnictwa). W celu doprecyzowania wskazanego związku można dodatkowo podać na przykład okres pochodzenia danych, co do których bank zostaje zwolniony z zachowania tajemnicy, bądź też rodzaje dokumentów. Takie rozwiązanie przyjęto także we wzorach dokumentów udostępnianych przez Rzecznika Finansowego ${ }^{36}$.

\section{PIŚMIENNICTWO}

\section{Źródła prawa}

Ustawa z dnia 23 kwietnia 1964 r. - Kodeks cywilny, tekst jedn.: Dz.U. z 2020 r., poz. 1740 ze zm.

Ustawa z dnia 17 listopada 1964 r. - Kodeks postępowania cywilnego, tekst jedn.: Dz.U. z 2020 r., poz. 1575 ze zm.

Ustawa z dnia 29 sierpnia 1997 r. - Prawo bankowe, tekst jedn.: Dz.U. z 2020 r., poz. 1896 ze zm.

Ustawa z dnia 17 lutego 2005 r. o informatyzacji działalności podmiotów realizujących zadania publiczne, tekst jedn.: Dz.U. z 2020 r., poz. 346 ze zm.

\section{Orzecznictwo}

Uchwała Sądu Najwyższego z 30 grudnia 1993 r., III CZP 146/93, Orzecznictwo Sądu Najwyższego. Izba Cywilna 1994, nr 5, poz. 94.

Wyrok Sądu Najwyższego z dnia 28 lutego 2018 r., II CSK 228/17, LEX nr 2486810.

Postanowienie Sądu Najwyższego z 17 sierpnia 2000 r., II CKN 894/00, „Biuletyn Sądu Najwyższego" 2000, nr 10.

Wyrok Sądu Apelacyjnego w Łodzi z 13 czerwca 2018 r., I ACa 1320/17, LEX nr 2571386.

Wyrok Wojewódzkiego Sądu Administracyjnego w Gliwicach z dnia 18 grudnia 2018 r., III SA/ Gl 916/18, LEX nr 2622861.

\section{Literatura}

BALwickA-Szczyrba Małgorzata: Przepisy ogólne o petnomocnictwie w kodeksie cywilnym, [w:] Marcin Glicz, Anna SylwestrzaK, Małgorzata Balwicka-Szczyrba, Petnomocnictwo. Komentarz, Warszawa: Wolters Kluwer 2020, s. 47-150.

BĄCZYK Mirosław: Zagadnienie dostępu petnomocnika do informacji objętych tajemnica banko$w a$, ,Prawo Bankowe” 1999, nr 2(24), s. 85-89.

BĄCZYK Mirosław: Czy w umowie może być umieszczone upoważnienie przewidziane w przepisie art. 104 ust. 2 prawa bankowego?, „Prawo Bankowe” 2000, nr 10(38), s. 89-92.

\footnotetext{
${ }^{36} \mathrm{https}: / /$ rf.gov.pl/pdf/Wzor_pelnomocnictwo_RF_WBK_bankowe.doc [dostęp: 4.03.2021].
} 
BĄCZYK Mirosław: Pelnomocnictwo zwiazane ze stosunkiem rachunku bankowego w praktyce bankowej, „Studia Iuridica Toruniensia” 2020, t. 26, s. 21-48.

BĄCZYK Mirosław: Komentarz do art. 104, [w:] Prawo bankowe. Komentarz, red. E. Fojcik-Mastalska, LEX nr 9095.

BYRSKI Jan: Tajemnica bankowa - aktualne regulacje oraz nowe wyzwania, [w:] Ochrona klienta na rynku ustug finansowych $w$ świetle aktualnych problemów i regulacji prawnych, red. E. Rutkowska-Tomaszewska, Warszawa: C.H. Beck 2017, s. 237-252.

GóRSKI Władysław, KiTŁowsKi Edmund: Prawo cywilne, Warszawa: PWN 1974.

JANICKA Krystyna, SŁOMCZYŃSKI Kazimierz: Struktura spoleczna w Polsce: klasowy wymiar nierówności, „Przegląd Socjologiczny” 63 (2014), nr 2, s. 55-72.

KARWIŃSKA Anna: Uwarunkowania dobrego funkcjonowania społeczeństwa. Znaczenie gospodarki społecznej, „Ekonomia Społeczna” 2010, nr 1, s.7-25.

Kосот Wojciech: Glosa do postanowienia SN z 22.02.2007 r., IV CSK 200/06, poz. 110, „Orzecznictwo Sądów Polskich” 2008, nr 10, poz. 110c, s. 474-754.

KRÓLIKOWSKA Katarzyna, KRÓLIKOWSKI Jakub: Zgoda klienta banku na przekazywanie informacji konfidencjonalnych firmom zewnętrznym jako narzędzie gwarancji konstytucyjnego prawa do prywatności, „Studia Iuridica” 2008, t. 49, s.105-124.

KróLIKowsKa Katarzyna: Komentarz do art. 104, [w:] Barbara BAJOR, Lechosław KociucKi, Jędrzej M. KondeK, Katarzyna KrólikowsKa, Prawo bankowe. Komentarz do przepisów cywilnoprawnych, Warszawa: Wolters Kluwer 2020 (Lex/el).

KsIĘŻAK Paweł: Komentarz do art. 43 Kodeksu cywilnego, [w:] Kodeks cywilny. Komentarz. Część ogólna, red. P. Księżak, M. Pyziak-Szafnicka, LEX nr 8935.

NAZARUK Piotr: Komentarz do art. 78, [w:] Kodeks cywilny. Komentarz, red. J. Ciszewski, P. Nazaruk (Lex/el).

OPLustil Krzysztof: Pelnomocnictwo do występowania na walnym zgromadzeniu akcjonariuszy spółki publicznej po nowelizacji k.s.h. ustawa z 5.12.2008 r., „Przegląd Prawa Handlowego” 2009, nr 11, s. 4-12.

RADWAŃSKI Zbigniew: Elektroniczna forma czynności prawnej, „Monitor Prawniczy” 2001, nr 22, s. 1107-1113.

Rokicka Ewa, Petelewicz Marta: Subiektywna jakość życia a status społeczno-ekonomiczny. Na przykładzie mieszkańców Łodzi, „Przegląd Socjologiczny” 63 (2014), nr 2, s.143-161.

SAGAN Marta: Tajemnica bankowa a prawo do prywatności w prawie polskim, Rzeszów: Wydawnictwo Uniwersytetu Rzeszowskiego 2021.

SMYK Marcin: Petnomocnictwo wedtug kodeksu cywilnego, Warszawa: Wolters Kluwer 2010.

SiKORSKI Grzegorz: Prawo bankowe Komentarz, Warszawa: C.H. Beck 2015.

SoBKowSKI Józef: Petnomocnictwo procesowe, jego istota, powstanie i wygaśnięcie, Poznań: UAM 1967.

SZOSTEK Dariusz, ŚwIERCZYŃSKi Marek: Moc dowodowa dokumentu elektronicznego w postepowaniu cywilnym, „Monitor Prawniczy” 2007, nr 17, s. 935-940.

SzPUNAR Adam: Stanowisko prawne petnomocnika, „Przegląd Notarialny” 1948, nr 1/2, s. 51-76.

SZPUNAR Adam: Ochrona dóbr osobistych, Warszawa: PWN 1979.

SzPUNAR Adam: Udzielenie petnomocnictwa, „Przegląd Sądowy” 1993, nr 9, s.18-34.

SzTOMPKA Piotr: Socjologia. Analiza spoleczeństwa, Kraków: Znak 2012. 
WIDERSKI Pawel: Petnomocnictwo w prawie polskim, Warszawa: Wolters Kluwer 2018.

Wolter Aleksander, Ignatowicz Jerzy, STEFAniUK Krzysztof: Prawo cywilne. Zarys części ogólnej, Warszawa: Wolters Kluwer 2001.

ZoLl Fryderyk: Prawo cywilne, t. I: Część ogólna, Poznań: Wojewódzki Instytut Wydawniczy 1931.

\section{Netografia}

http://www.adwokatura.pl/z-zycia-nra/knf-po-pismie-nra-interweniuje-ws-niehonorowania-przezbanki-pelnomocnictw/.

https://rf.gov.pl/pdf/Wzor_pelnomocnictwo_RF_WBK_bankowe.doc

Inne

Pismo KNF z dnia 8 grudnia 2015 r., DRB/DRBI/075/21/4/15.

Wrona Joanna, PIŁKA Mirosław, BuDZICH Krzysztof: Ustugi bankowe w aspekcie ochrony praw konsumenta. Raport z kontroli wzorców umownych uznanych za niedozwolone, Warszawa 2003, https://www.uokik.gov.pl/download.php?plik=11214.

\section{UPOWAŻNIENIE DO UJAWNIENIA TAJEMNICY BANKOWEJ OSOBIE TRZECIEJ A PEŁNOMOCNICTWO}

\section{Streszczenie}

W artykule poruszono problematykę dostępu osoby trzeciej do informacji objętych tajemnicą bankową. Na podstawie obowiązujących przepisów Prawa bankowego, osoba ta powinna zostać upoważniona przez beneficjenta tajemnicy. Zarówno w doktrynie, jak i praktyce stosowania prawa niejednolite są stanowiska dotyczące możliwości udzielenia przez bank takich informacji podmiotowi legitymującemu się pełnomocnictwem. Zaprezentowano $\mathrm{w}$ zarysie rolę instytucji tajemnicy bankowej z uwzględnieniem jej gwarancyjnego charakteru. Odniesiono się do charakteru upoważnienia oraz pełnomocnictwa, a także poczyniono uwagi dotyczące form tych dokumentów. W podsumowaniu przedstawiono wnioski mające bezpośrednie zastosowanie w praktyce.

Słowa kluczowe: forma dokumentu; tajemnica bankowa; dostęp 